$$
\begin{aligned}
& S B 259 \\
& \angle 5
\end{aligned}
$$


Hollinger Corp. pH 8.5 


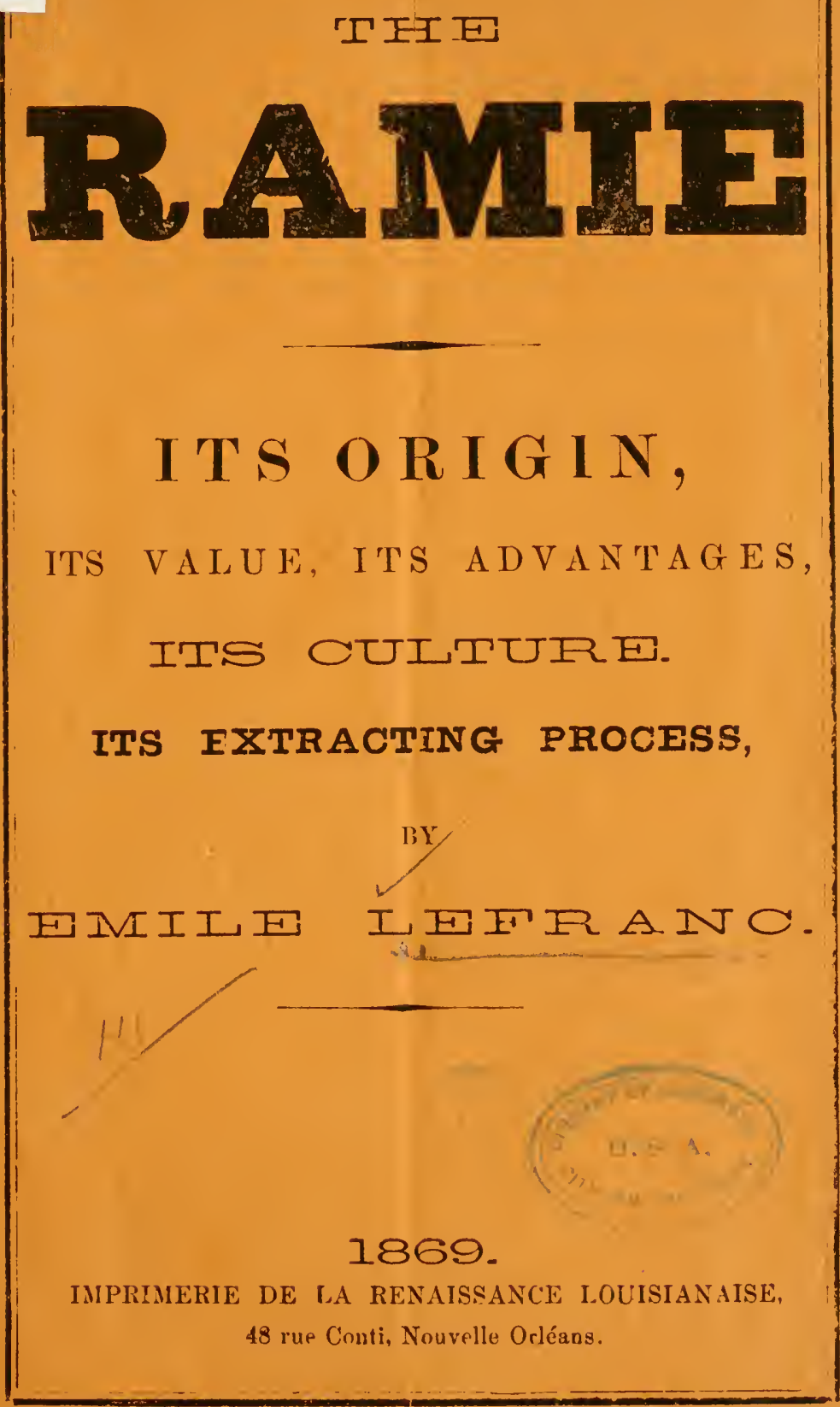




\section{B ES}

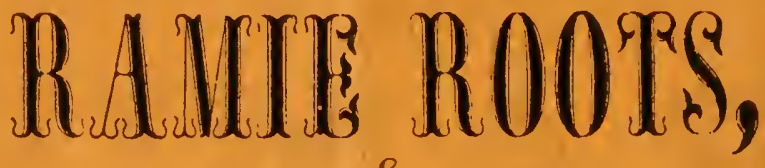

GUARANTED TO GROW,

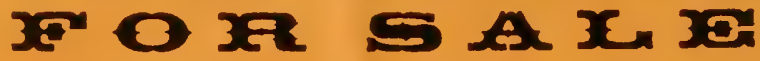

ON THE BEST TERMS

B Y

EMILE IEFRA N C,

RENAISSANCE LOUISIANAISE OFFICE,

48 CONTISTREET, NEW ORLEANS.

Almost two years of practical labor in introducing and cultivating the Ramie plants entitle Mr Lefranc. to all patronage and confidence. He has several nurseries in full growing.

ALSO FOR SALE BY THE SAME IEFRAIC \& CO'S RAIIIE AID OTIIER TEXTLLES

\section{EXTRACTING MAGHINE.}

The undersigned, having transfered his Ramie agency to this general nursery depot of the roots, informs the public that all communications or orders for roots or the filure extracting Machine addrensed to him, will be promptly attended to from La Renaissance Lonisianaise office, 4S, Conti street. New-Orleans.

J BRUCKNER. 


\section{F J}

ITS ORIGIN, ITS VALUE, ITS ADVANTAGES, IT'S CULTURE

\section{ITS EXTRACTING PROCESS.}

The South being forced by necessity in the pursuit of some congenial culture which can be profitably adapted to her actual system of reduced labor, and to her precarious ressources, the cultivation of Ramie is the only industry that can attain the object, and realize the profits of the past in applying itself to the aetual conditions of the present.Cotton in the Soutl, is subjected to such uncertainties as to make its culture risky; sugar requires so much capital that but few planters ar $>$ able to support it.

Ramie alone is apt to become a general and democratic source of prosperity for all. It fears no danger, lias no ennemy, requires littlo labor, needs but a small starting capital, propagates rapidly, sells high and moreover can become a monopoly for the South, because our soil and climate are superior to any other for the growth of the plant.

Its fibre quality is here finer, whiter, longer and stronger than even in the East Iudies. When in its original laud, the stems grow to only 5 and 6 feet high; in the Southern soil it rises up to 10 feet. That is the reason why the learned and sagacious botanist Roelzhas, out of many lands, selected our fertile States as the best field for these precious. roots.

Already, several plantations around us are progressing to such an extent that they sell to neighbours plants enough to replace their first investment, and soon the New Orleans and New York markets will be open to the new textile. Then, fortunes will be made by the energetic and enterprising planters who will not have been afraid to go into the cheap experiment.

It is believed that the actual price of $621_{1} 2 \mathrm{e}$. obtained for the fibre per pound will fall according to the extent of the produetion Such may be the result after a long time. But should it fall down to $25 \mathrm{c}$. it would be still remunerative and assuredly more profitable than any other culture. The question of this falling price is hovever very doubtful; it may also be that, instead of decreasing, it will increase considerably. For these roasons: Tith the production of such a fine aud durable article and its introduction into the general wearing, consumption will certainly increase and create great demand all ovtr Europe and the American continent. Such a domaud being applied to a relatively small center of production as Louisiana and two or three States around having the monopoly, prices will rather be mantained firm and ascending than otherwise. This simple result can be easily understood from the very fact that European and New York houses. having heard that the South is engaged in the cultivation of Ramie, al $\theta$ calling in advance for all that shall be produced. English markets are long since receiving this fibre from China and different sections of the East Indies. But the quantity thus received from so far a point is so contracted and irregular that the manufacturers never could furnish to general trade a sufficient stock to make of it an article $o_{i}^{n}$ general use. Only a few mills in England, Germany and France have 
secretly maunfactured the fibre by mixing it with Cotton or silk for some superior tissues. And generally the lace fabrics have used most of what Europe has imported. The cause of such limitation is in the insufficiency of the importation, and the cause of that scarcity is in the difficulty of extracting the fibre in India.

So far, the Orientals have not found the proper macinery for extracting the textile from the lignous plant; they do it by the primitive and slow process of a knife and of their fingers. The time expended in such manual labor gives two results which militate against the exporting trade: Shortness of the product for home consumption, and, consequently, elevation of price for the article, especially when it has to bear the high freight and insurance of a long voyage on the Ocean. The mother-cause of these difficulties to introdnce the article into use and intogeneral commerce is removed and annihilated by a proper $\mathrm{Ma}$ chine for extracting and cleaning the fibre of Ramie. This machinery is no longer wanted. We have it, as the reader will perceive it furtber.

\section{Origin and Value.}

Ramie, scientifically called the "Urtica Utilis" belongs to the family of the "Urticea" which embraces a great variety of plants, of which the common nettle, the Hemp and the flax are the most generally known.

Dr. Leclancher, surgeon on board of the french man-of-war la $F a$ vorite, and Dr. Roxburg, the English botanist, were the first to call the attention of European industry to the value of this extraordinary fibrous plant.

The fibre extracted from it when sufficiently cleaned is perfectly white; it has the brilliancy of silk, is finer than sea Island cotton, su perior in strength to the best flax; and its durability is such, that the inhabitants of Java, says "the Universal Dictionnary of Natural History" give to this fibre the preference over all others for the manufacture of their dresses, which are extremely fine, as also for their nets, fish lines and ropes; and the fibre is so tenious, according to the same authority, that from an experiment made upon 500 grammes [one pound] of it, a thread 9,300 métres [over 10,000 yards] was obtained.

The Ramie plant originates frem Java and has been extended since several centuries all over the southern section of Asia, where it is cultivated and spun on a large scale for home consumption and export. The fine silky goods known under the name of "Grass eloth" "China and Japanese silks" are nothing but Ramie or China-grass fabrics.

For many years past, some European manufacturers have imported the raw material, that is [Ramie fibre in a crude state, and have succeeded in producing excellent goods of Ramie, pure or mixed with coton and silk. These enterprising manufacturers have all made large fortunes by keeping the secret of their product and having the monopoly of the new article.

In 1862, the laborious botanist Benito Roëlz introduced a few Ramie plants from Java into Mexico, at Santo Comapan, near Vera-Cruz.

It succeeded very well. It was propagating luxuriantly there when the fall of the Mexican Empire brought so much disorder in the country that M. Roëlz had to leave the place. He came to New Orleans in 1867 with a limited quantity of roots.

MI. Roëlz appointed as his agent in NewOrleans the writer, editor 
of the Renaissanee Louisianaise, a french weokly paper particularly devoted to the progress of agriculture and industry.

Through the influential medium of the Southern press, and especially of this publication, which diffused the knowledge of the staple and demonstrated with pertinacity the advantages of its culture, Ramie was introduced in the South. Essays made in Louisiana, Mississippi, Texas, Alabama and Florida proved that it grows anywhere in warm latitudes. Whenever the earth does not freeze deeper than four inches, the plant grows continuously, yielding at least four crops a year; each crop producing not less than 400 pounds of clear fibre per acre.

European markets are readily open at good prices for the product. Ramie fibre is actually quoted in Liverpool, in the circulars of Alexander McCre and other brokers, at the following rates : raw staple, from 9 to 12 cents per pound, in gold; half crude, from 20 to 35 cts.; finished and refined from 65 to 70 cts.

Manufactories exist now in England, France, Germany, Belgium, where this fibre is used with the greatest success, either by itself, or mixed with cotton silk or wool; and the annexed letter from Messrs. Wade and Sons, large manufacturers of BRADFORD. England, to the author of this pamphlet, speaks for itself and gives a fair idea of the value of the Ramie fibre:

\section{BrAdFord, Aug. 22, 1868}

\section{E- Lefranc, Esq., Fidor of the Renaissance Louisianaise}

Dear sir-IVe are in receipt of your faror of July 28. We enclose you sample of China grass as we buy it in London at from $45 \mathrm{~s}$. to $55 \mathrm{~s}$. per ton; also sample of the same dressed, which is worth about 2s.6d. per pound - the price being ratber low at present, owing to our trade being somewhat depressed.

We cannot judge your sample as to price. Ours, you will see, is much better got up than yours. We have used China-grass for many years, with increasing snccess, and have no doubt, in time it will become an important article of commerce. We enclose you samples of goods. We are making cotton warp of China-grass weft, also Chinagrass yarus. We shall at all times be most happy to give you any information in our power, We are, sir, yours, truly,

\section{JosepII WADE \& SONS.}

$62 \mathrm{I}_{[} 2 \mathrm{cts}$. in gold per pound for the best cleaned fibre, and 121 [5 cts. for the raw article, leave room for intermediate grades at say: 25, 30 and 35 cts. gold per pound" which would certainly realize the most sanguine expectations of planters.

\section{Opinion of the Press.}

The Southern and even the Northern press are unanimcus to recommend a prompt and large cultivation of the new plant. Here are a few extracts from news papers lecommanding the enterprise :

Wo publish with great pleasure the letter of Joseph WVade and Sons of Bradford. England, to M. Lefranc, and the letter of that gentleman to ourselves on the subject of the ramie plant, We look with especial interest on this experiment, because the great object of the southern planter is now to obtain as much product from the natural agencies of soil and climate, and as little from that most expensive agent of production, labor as possible. In this they obey the law of 
free labor, which the world seems to prefer, and they but copy the efforts of those who employ free labor to liberate themselves by machinery and other agencies from an expensive and desagreable dependince upon labor.

Machinery will be, of course, necessary to prepare the ramie for use, and will enter much into the comparative cost of this and othor textile staples.

We liave been favored by M. Lefrane with epecimens of the ramic cloth, both of fine and medium texture. It is a fine and beautiful article and looks as if it would wear like tin. Wo hope our planters will pursue the experiment. A correspondenee tith M. Leframe will give them all the information necessary, and also we think enablo them to secure "creole roots" for immediate use.

(New Orleans Commercial Bulletin.)

The Ramie and its products.-Emile Lofranc, Esq., our able and courteous contemporary of $L a$ Renaissance Louisianaise, has received some very beautiful samples from MLessrs. Joseph VVade and Sons of Bralford, England, of tissue made from the Rarnie plant. These fabrics are exceedingly fine and light, are dyed yellow, bluo and purple, and appear to unusually strong and durable. Wade and Sons import their Ramie fibre from the East under the name of "China grass." When dressed, this fibre now has in the London market a value of $2 \mathrm{~s}$. 6d. per pound, equivalent to $6211^{2}$ cents in gold; which is a splendicl renumeration to the planter. Mr. A. Ferry, an intelligent ramie cultivator in the parish of St-James, estimates the average yield of clean fibre in Louisiana at fifteen luundred pounds to the acre. At this time there are probably fifty agriculturists in different portions of the State who have given their attention to planting the ramie on an extensive seale. Wherever information has been reeeived from these gentlemen, the plant is reported as thriving admirably. It seems to flourish more vigourously and luxuriantly in our soil than even in the distant counltry whero it was first known. The ouly thing necessary to make New Orleans a great market for the ramio plant, in all its processes, from the rav fibre to the finest tissues, are the erection of the requisite machinery and the more extended cultivation of the plant itself.

This subject is one well worthy of careful investigation of land owners in both Louisiana and Mississippi.

\section{(New Orlcans Crescent.)}

Wo are glad to learn that the experiments made in this State in the production of the ramio plant have proved entirely succossful. Quitu a number of planters have become interested in thie new textile article, and no doubt is entertained by them that in our soil an annual crop of 1500 pounds per acre can be raised. If this estimate be at all reliable the crop must prove splendidly renunerative at the price offered in England-2s. 6d. per pound. We have been kindly furnished with speeimens of ramie cloth, and in this connection the letter to our contemporary of the Renaissance will prove interesting.

(New Orlsans Picayune.)

The New Orleans 'Times, tho Bee, the Republican and almost every publication in the country speaks in the same laudatory and eneournging terms of the ramie eulture and product. Besides theses commendations, the goverument has spoken also in firor of the now 
industry. The agricultural reports of 1866, 1867 and of 1868 give advice and informations encouraging the ramie culture. Every scientific and practical man, hotanists, economists, and manufacturers entreat the rural penple to plant Ramie.

\section{ADVANTAGES OE TIIE RAMIE.}

Ramie yields a finer fibre thau Sea Island Cotton, stronger than the bost flax and as brilliant as Silk.

Ramio require less labor that Cotton and its growth is perennial.

Ramio is not destroyed by Caterpillars; the product of one acre of Ramie is equal to the profit of six acres of Cotton in its best crops.

Ramie stands good for ycar's and years, without replanting.

Ramie is harvested three or four times a year.

Ramie don't suffer from excess of rain, and withstands the longest drought without injury.

Ramie is already naturalized in the Gulf States, and its adoption where Cotton has been cultivated, is securgd.

Ramie will be the means of re-establishing the Southern prosperity through the rapid extension of the plant.

Ramie may be taken from the field in the morning, and in a fow hours after give a nicé and fine fibre ready for markot.

The Ramie plant is a hardy and vigorous grower. It is started with root cuttings planted three inches in the ground, in good loose soil; can be propagated by layers, cuttings and divisions of the root, with great rapidity, and can be multiplied at the rate of a hundred for one in every month.

-The Ramie ban be planted and re-planted from the roots at any senson of the year. and neod not be renered for many years and requires less labor than any other culture.

IVell rooted plants will produce at least 1500 lbs. per acre of fibre, which sells now in London at $6211^{2}$ cents per pound in gold.

The fibre of this plant is, when cleaned, purely white, far finer than than Cotton or Flax Linen, and stronger than either. The plant in a warm latitude, is perennial. and the crops from it are taken like those of cane, by cutting it close to the ground; from the rattoons a new growth springs up at once. Rich sandy ground suits best, but it is so vigorous that it will do vell anywhere, and the roots or pieces of roots and stalks can be used to increase the plantation in any land.

The experiments of the eminent botanists Roxburgh, Belastier, Forbes, Leclancher and other's satisfied them as it did Dr, Benito lioezl, that Ranie poscessed the following advantages :

The fibra is stronger than that of the best European-homp.

That it is fifty per cent strunger and better than the Belgian flaxen (r linen fibre.

That it can be spun as fine as that of flax, and that it is of double duability.

That the plant is a vigorous giower and will produce far the greatest. amount of textilo fibre of any plant hitherto known.

In countries, where fiosts aro light, fall plantings can be done with ils inuch success ns in spring.

Planting in the fall of the year gives the plant the advantage of taking root durigg the winter, and sprouting, early in tho spring

\section{CULTIVATION ON THE RAMIE.}

'The ground has to be plowed twélve inches deep and pulverized, and clenned of all woedy roots. Than work it in furrows four feet 
apart; then place the roots obliquely [1] 3 inches under the surface of the ground, one yard distant. 'The plant will then sprout out soon, and appear like bushes. As soon as they are six to eight inches high, the whole of these is to be bound down to the ground and covered witn earth, and nothing but the tops ought to be seen. This is to propagate the plant.

After four or five weeks all the stems thus bedded will be overgrown with roots. These new young plants are to be cut off and transplanted or sent, when ripe, to the machine for extraction. Meanwhile the mother plant will sprout again, to be operated on as at first.

A little labor is required only for the first year, after which hardly any labor will be necessary, except for cutting, gathering and cleaning, and even this does not amount to much.

It can be propagated with the greatest rapidity from layers, cuttings and divisions of the roots.

One acre planted with roots and properly propagated will produce sufficiently to plant the following year 200 acres.

The caterpillars or other worms do it no harm, the fibre being inside of the bark of the stalks.

The labor required even for the first year is less than that required for cotton and for sugar and by no means so pressing and risky.

All lands are adapted to its culture, specially those where corn, cotton or sugar would grow; bnt in rich sandy soil, the profit would necessarily be much greater. The bushes, plants and roots, can be unrooted and removed easily from a piece of land to another; and it does not affect, in the least, the quality of the soil.

\section{ITS NURSERY CULTURE.}

The culture of the Ramie being altogether a novelty in this country, it is necessary that some general rules should be established,

The Ramio is planted from roots, not from seed. The roots for salo being so limited in number, and held at so high prices, it would be impossible for planters to begin planting at once on a very large scale; nt 25 or $20 \mathrm{c}$. per root, it would require too large a capital to cultivate from the start on a large area of land, and planters are therefore com. pelled to begin with a few thousand roots, and make their own seed. Hence the subject of the fculture of the plant is necessarily divided into two parts :

1st.-The culture on a small scale to propagate and provide for roots;

2d. - The culture in the field to make crops of fibre.

In both modes, whether on a small scale to make roots, or in the field at larae, the land must be ploughed deeply; the deeper, the better: and with a plant like this, lasting years and years, the planter cannot be too particular in this respect; 10 to 12 inches in the field would not be too deep, and in the nursery, to provide for roots ploughing to 15 and 20 inches would prove very profitable.

After this is done, the ground must be pulverised and cleaned of all weedy roots.

Then place the roots in the ground 3 inches deep, in furrows six feet apart, and in the furrows, the roots six feet from each other.

Three weeks or a month after, the plant will begin to appear above the ground; each root will produce on an average for the first growth from 10 to 15 stems; these in the course of about a month, will bo nearly 3 feet high; at this period, they must all he laid on the ground 
and covered with earth, 2 inches deep, lcaving uncovered only the 2 or 3 small top leaves. 30 days after, if the weather has been wet, 40 , if dry, they will be perfuctly rooted.

The mother plant with the portion of rooted stems attached to it wlll then have a radiant diameter of nearly 4 feet.

New ratoons or stems will immediately spring from the ground; not on an averaga of 10 or 15 as in the first growth, they will number this time 80 to 100 to each plant.

These stems being so numerous, it would be impossible to lay them all in the ground; cover them as many as practicable, in the same manner as with the first growth, leaving the balance to mature.

When those left standing are ripe, and this will be known when they become of a dark brown color, cut them off from the plant close to the ground; throw off all the upper part which may have remained green, and plant the derk brown portion in the rows of the field, lengthways, as the sugar cane, leaving however about 2 inches of the stem out of the ground.

It will readily be perceived from the above remarks, with what rapidity the plant will propagate and may be spread over a large tract of land, and at a very littlo expense. The quantity of roots for planting a nursery is of 2,500 per acre.

We now come to the

\section{Culture of the PlaNT in LARGe Fields.}

This may be resumed in a few general remarks.

The land must be prepared as in the first instance, with the exception that the ploughing is not required to be so deep, 10 to 12 inches will do, although, we repeat it, the deeper the ploughing, the better the crop, and this is the hardest of the labor, but it will amply renumerate.

The land being well ploughed and cleaned, the layers obtained from the mother plant, as already explained, must be planted 3 feet a part in rows, 3 or 4 feet distant from each other. When well rooted, the few stems of these layers must be cut off near the ground, to force the new ratoons to spring from the root, and four weeks after the entire field will be covered with fine green bushes of Ramie, which every two and a half months will yield crops of stems from which the extracting machine will draw a fiue white, silky fibre. each crop being of 4 or 5 hundred pounds to the acre. After the second crops, the field will be as thickly covered as a wheat field, and it will remain so for years.

After a year the plant will have so many ratoons that other plants will have no room to vegetate. Even the Couch Grass (coco) will be suppressed by the strong vigetation and shade of the Ramie. From this time, the cultivation will give very little trouble, except one ploughing between the rows early in the spring.

The planting in the field ought to be done in the spring, but can be continued until late in October. Culture in large fields requires 4000 roots per acre; close planting gives sraight stems and more fibres.

\section{FOREIGN TESTIMONIALS.}

Foreign countries, as France and England, have made attempts to introduce the Ramie culture in their respective soil but, the intense cold and dryness of the atmosphere, have worked so against the experiment that all efforts bave been unsuccessful. The plant requires, 
to give a good product, a moist and worm climate as well as rich lands, as in our latitude.

'The Scientific Society of Acclimatution, one of the most eminent bodies of european savans, has published in its aunual report some very interresting informations in regard to Rumie planting in $\Lambda$ sia.

M. Dabry, french consul, at Haw-Kéon, and correspondeut of said Society, says that Urlica Nivea, or liamie is largely cultivated in the Chinese provinces of Hou-man and of the Kang-si under the name of Tchout-ma. The planters do not raise it from seed, which is very lnng to grow, they operate with the stalks and roots laid in furrows of three inches deep. They place the roots as close as one foot apart, to have straight and thick stems. 'Their lands being rather poor and ex. hausted they put inanure over the roots and succeed so well as to inake threecrops. They extract the fibre with their own hands in breakiog the stems and in skiuning the bark, whicl, put up in bundle, is hunged in a closed room, where it is dryed and whitened by sulphur smoke. In the State of Queen's Land, Australia, says the report, the culture of China-Grass, Urtica-Nivea or Ramie, has given the most liappy résults. Thougl experiments have been made on a rach $1+1^{\circ}$ loose and careless system, the plant has grown with an extraordinary profusion. The government has encouraged the Ranio culture, but, so far, the absence of any mechanical nower or contrivance to extract the fibre has been the drawback of the progress. The french goverr ment has introduced the Ramie culture in its oceanic islands, of wlich the Count de la Roncière is the governing agent. We have been commissioned by the French consulate of New-Orleans, to send s9veral hundred roots thither. The Count has had them planted with success in the Socioty Islands, where it propagates now very rapidly.

From all quarters, as it will be noticed, thece is reports concurring in proving the fact that the Ramie plant is a great source of wealth for the people, who like southerners, are privileged with a climate, a soil and meclianical means, most luskily adapted to tho new industry. Talent in labor, capital, spirit of enterprise and genius, are neither wanting in our midst; better situated than the Oriontals, we will make quick progress in the use of this precious fibre.

We liave already solved all the agricultural problems and wo are now going to solve the mechanical ones. We possess the machino so much wanted.

\section{THE MACHINERY.}

The agricultural problem of the plant boing completly solved with success, we have now to solve the problem of the extracting machinery which produces the fibre. Several common hemp breakiug machiues lave been applien to the Ramis stems, but, so far, have not given ample satisfaction. To make the Ramie stem jicle its rich fibre, we have constructed a machine of our own iuvention which answers to all the requirements of economy, promptness and farility of operation. Experiments made have proved the efficiney of this macline; it is a system of rollers disposed so as to hreak and clean a liurge quantity of Ramie. It can be taken on the field and rorked either by mén or horse power as woil as by stuam.

Its management consists in bringing forth bunches of stems and pushing them through the rollers, with somie particulur directions which shall be given in a sprecia prospectas.

In proper time, ample instructions shall be published in regard to the 
general process for obtaining a white and silky fibre out of the plant with this instrument.

The writer will have this machine for sale at a price which shall not exceed $\$ 300$. It shall be exhibited at the Louisiana State fair next April.

\section{EXTRACTS FROM THE AGRICULTURAL REPORT.}

OFFICIAL.

AGRICULTURAL REPORT FOR 1865, pages 349 and 352.

"Of course, the grass manufacture is yet in very few hands, of which Messrs. Wade are the most important; but its development already, even within the last few month's, has beeu signally rapid. The market value of the raw material has, for some years past, maintained ittelf at the very high rate of about eighty pounds per ton, which price it is supposed, cannot be much lessened for many years to $\operatorname{com} \theta^{\circ}$ Two things are certain in this respect: one, that there is now, and will be, here a practically limitless market for all the raw grass that can be imported, at from $£ 7()$ to $£ 80$ per ton; the other, that under any fluctuatious of the market, the material is intrinsically so va!uable that it will always, in the future, command a price as high as that of cotton, and nearly or quite as high as that of worsted itself, if not even higher

Here, then, is a great and increasing market for a certain vegetable production at a very high price. In America we have, on the other hand, vast tracts of country, which being in the same latitude and with very much the same climate as those districts of China, of which the grass is native, we should be able to grow this produotion to great advantage. Why not, then, introduce its culture? I submit that these facts constitute a prima facie case for the very serious consideration both of the Agicultural Department at Washington and of our enterprising planters and farmers throughout the South.

Recent improvements in the manufacture of this fibre, as seen in specimens received from individuals in this country and Great-Britain, have excited considerable interest, and elicited inquiry; in fact, the subject came before the Senate of the United States, in connection with a letter [enclosing samples of goods] of Mr. William H. Richard, of Boston, and a resolution was adopted calling upon the Senate Committee on Agriculture to "investigate the subject of procuring the seed and cultivating the "China-grass."

\section{AGRICULTURAL REPORT FOR 1866, page 21.}

"Esperiments with this plant have resulted improving that it can be grown successfully here.

\section{AGRICULTURAL REPORT FOR 186\%, page 224.}

"The China-grass cloth has long been known to commerce, and the fibre was many years since brought to Europe, where it atracted the attention of manufacturers for its fineness, strength and beauty. It was found to be stronger than hemp, with the lustre of silk. At the British International Exposition of 1862, several specimens from India, Assam and Malacca were exhibited. The report of that exhibition referred to these samples are attracting more attention than any other products of India, it stated that late experiments had shown that the fibre was succeptible of manufacture in a great variety of useful and valuable fabrics." 


\section{$-10-$ \\ EXTRACT \\ From the N. O Price Currert December 2:3 1863.}

The following are answers to questions often asked about Ramio:

Firstly-Ramie or China Grass is botanically named "Bochmivia Tenacessinia", of the order "Urticacia," so that no one need mistake it on inquiry.

Secondly-It is neither unlike jute or hemp, but with a bolder, cris. per, yet more pliable fiber.

Thirdly-To be got up in proper way [I speak of the raw material,] it should be dried, when the green becomes white.

Fourthly-The value in a green state is $£ 35$ to $£ 40$ per ton of 2,240 lbs.-white, $£ 50$ per ton-dressed for mising with cotton and silk, $£ 280$ to $£ 300$ per ton.

Fifthly-Applications.-Any Americans who have visited this side the last year or two may have seen our ladies wearing for morning and walking dresses what might appear to be a splendid French Lavender silk! American ladies, however, would not fail to observe that though beautiful to the eye, it lacked the inherent value of silk to the touch, though superior in every way to cotton. Did any one of these American visitors know that this silk like material owed its base to their own soil-that it was chiefly made from Ramie or China.grass-and is no other in Europe than the imitated, and so called "Japanese silk ?"

'The Liverpool circular of Alexander S. Macræ of the 25th ultimo, contains information of much interest value to parties who have alrea. dy cummenced the culture of the Ramie plant, and to those also who contemplate doing so. Comsidering the comparatively small amount of labor and expense attendant upon the cultivation of the Ramie as compared with other crops, and the large profits which it affords, it would appear a little strange, unless some attention is given to the subject, that there has not been more progress made in cultivating it in the extreme Southern border, and sarticularly in our immediste vicinity. That the Ramie will, in time, be largely and profitably cultivated in the States bordering on the Gulf, we think there can be very little question, and the reason, we think, why its culture has not been more extensively attempted is owing to the fact that it was introduced to the public at an unfavorable period. Since the war the necessities of our people have been so great that few could afford either the time or the means to experiment, or to embark in any occupation which was not well understood, and certain to yield something to live upon.

The situation, even yet, is not greatly changed in this respect but still the improvement is such that many of our people will probably be induced to devote a portion of their lands hereafter to the cultivation of the Ramie Should this course be pursued, it will necessarily lead to the erection of suitable machinery for cleaning and preparing the $\mathrm{f}$ bre of the Ramie for market, and once this progress is made, and the businesss is found to be half as profitable as it is claimed that it will be, there will be an increase of its cultivation even should the money value per acre of Ramie be no more, or even sumething less than is yielded by cotton, the advantage being so greatly in favor of the former on account of the fewer laborers required, a most important consideration now, and destined to be still more 30 in the future.

The plant grows splendidly well in Louisiana, and it can be seen in all its luxuriancy at my different nurseries around Now Orleans. 
It has been said that the Ramie, once introduced in a land, cannot be removed and that it becomes a nuisance. This is entirely erroneous; the Ramie bushes can be unrooted with the greatest ease and the roots extirpated by ploughing as well as any other plant-Sugar cane, Corn, Cntton, \&, \&, \&.

We conclude this fair statement of facts by assuring that the resalts of over one year of constant experiment 3 have proved that there is no exageration in the promises of this Pamphlet.

\section{PLANTING AND HARVESTING ILLUSTRATED.}

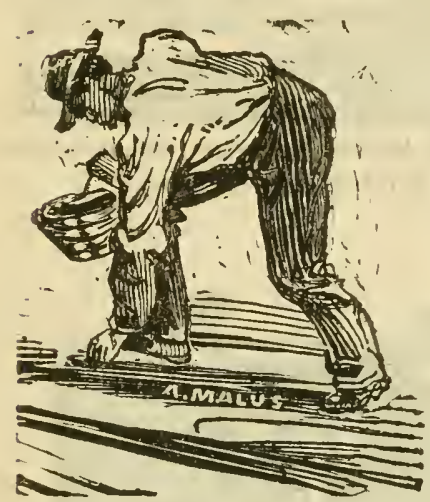

The above figure represents a laborer placing the roots in the furrow. The root, fresh and wet, is placed in an oblique position in the middle of the line. The land must always be moist and fine.

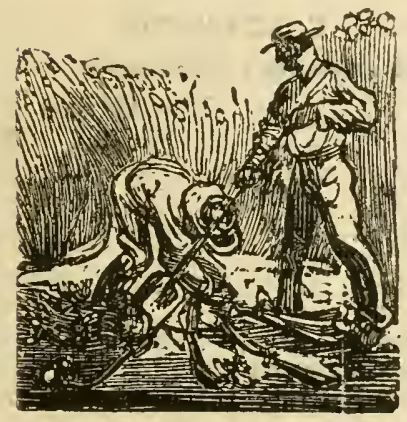

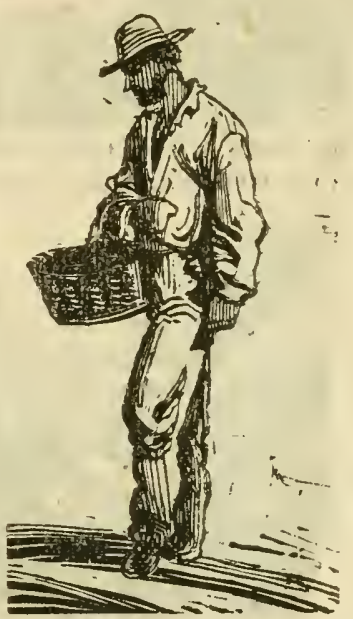

The above represents the same man in an erect position. He covers the root with fine ground by jerks of his feet.

This figure represents the laying process. A man keeps the stems down to the ground and another bury them under two or three incles of dirt. 


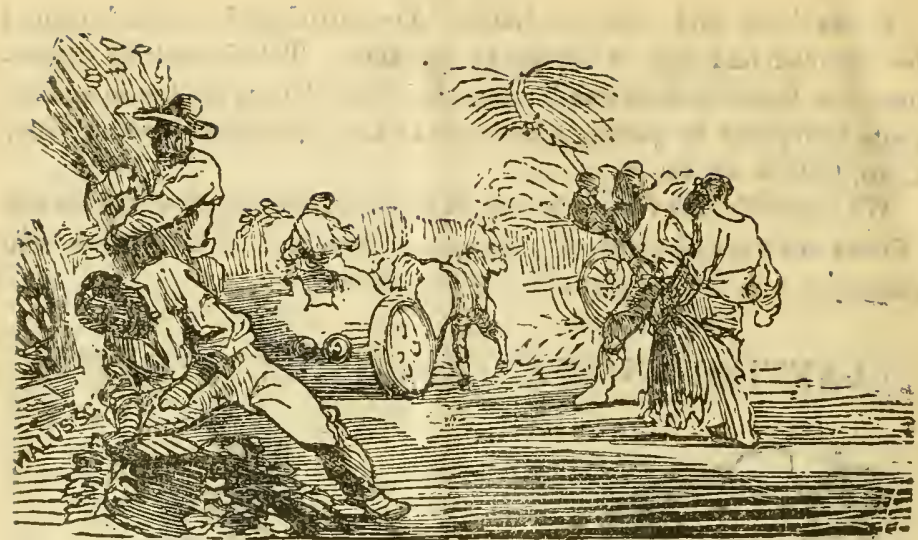

The above shows the mowing and harvesting labor; the maohine cuts; the men bundle and convey the stems as hay or wheat.

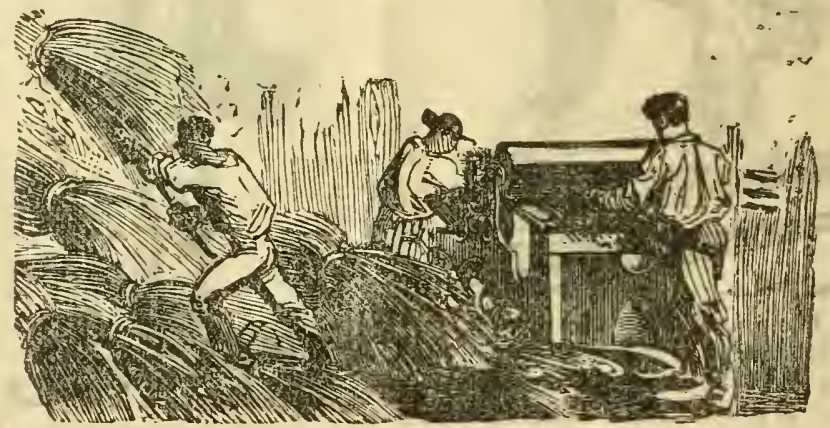

The above shows the breaking process by machinery. The first operator directs the stems by bunches to the rollers: the second receives the cleaned fibre and the third sends it towards the washing tubs, where the glutinous and woody matter is dissolved or disintegrated from the textile.

\section{E. LEFRANC.}

Editor of "La Renaissance Louisianaise."

New Orleans. 


\section{LE}

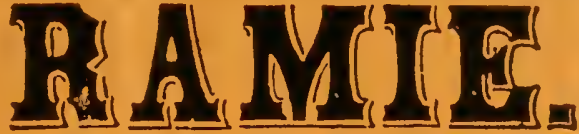

\section{SA GUMUUYRE, SA WAXEYYR.}

La culture du ramié est reconnue comme devar، être une nouvelle source de richesse pour le Sud. Elle ne convient qu'aux climats claads et aux ter. res humides; nous en pourrons tirer un monopole durable. Le travail de cetie innovation est facile et non dispencieux. En voici l'instruction en peu de mots.

Plantez la racine à une yarde carrée d'espace, comme on plante la pomme de terre; les prenières pousses seront, en deux on trois mois. assez hautes pour être renfouies. Marcottez-les et laissez ffaire souche. Si vous voulez propager, faites des boutures avec la seconde pousse, dès que les tiges auront pris corps et quelques pieds de hauteur. Chaque bout de cinq à six pouces suffira pour faire un nouvean pied. Lorsque la souche sera assez epaisse pour rapprocher sa voisine, deterrez et faites du plant avec les fragments des rasines extraites. Le sol louisianais est si propice à la reproduction que cent pieds ont reproduit jusciu'à cent mille pieds par an. On commence à cruper dès que lea tiges mûrissent; ce qui s'annonce par l'altération des feuilles et par la noircissure de l'écorce

Le ramie est une ortie, et sa fibre étant contenue dans l'écorce comme le chanvre, les chenilles ni les insectes rongeurs ne peuvent l'atteindre.

Le procédé de lextraction par la machine consiste à presenter en brassées les tiges à la denture du cylindre tournant La force d'un homme suffit à la rotation. Une seule personne peut l'alimenter. La fibre collante extraite de la tige dégage su gomme et ses matières végètales dans un bain de lessive. Elle blanchit et prend sa forme de filasse en séchant. Le rendement est, en Louisiane, d'au moins 1,500 livres de fibre par arpent.

Il est prouvé que la culture du ramié donne plus de profit et exige moins de travail qu'aucune autre récolte. Ia fibre vaut actuellement $60 \mathrm{cts}$. la li vre en Europe; des maisons du Nord ont retenu d'avance tout ce qui se produira. L'immense consomınation qui s'en est fait en Chine et aux Indes est un sûr garant.de sa valeur commerciale.

Ies feuilles et la pulpe des tiges broyées font ane excellente matièro pour la fabrication du papier.

\section{Dépôt à la RENAISSANCE LOUISIANAISE, 48 Rue Conti.}

Prix du plant: $\$ 25$ le cent de pieds, ou $\$ 200$ le mille

A VEXURE-LA MACHINE à extraire la fibre du Ramié ou de tout autre textile it l'état vert.

$$
\text { Priz: } \$ 300 \text {. }
$$




\section{표}

a aaa 0218792

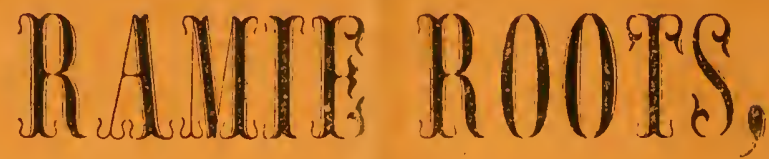

$$
\text { GUARAN }
$$

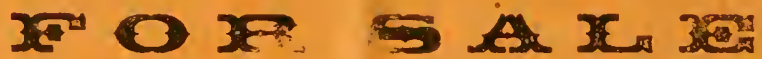

ON THE BEST TERISS

\section{li $\mathbf{Y}$}

\section{EMILM LIEFA N $\mathrm{N}$,} RENAISA ANCE LOUISIANAISH OFFICE,

48 CO N T I STRE ET, N E W OR L E A N S.

Almost two yeaís of practical labor in introducing and cultivating the Ramie plants entitle Mr. Lefranc to ali patronage and confidence. $\mathrm{He}$ has several nurseries in full growing.

AISO FOR SAIE BY THE SAME GA

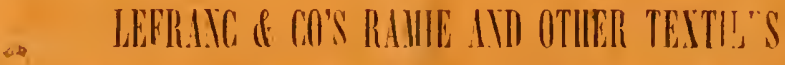

\section{EXTRACTUG MAGHNE.}





\section{LIBRARY OF CONGRESS}

|||||||||||||||||||||||||||||||||||||||||

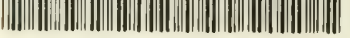

00009318793 